\title{
Congress requests bubble-fusion reports
}

The US Congress has asked Purdue University for reports of its inquiries into allegations against nuclear engineer Rusi Taleyarkhan.

The request is one of the first actions from the House subcommittee on Investigations and Oversight, which was re-established in January 2007 when the Democrats took control of the US House of Representatives after twelve years of Republican majority. The move suggests that Congress is preparing to take a more active role in investigating the way that publicly funded research is policed.

Taleyarkhan has published several controversial papers claiming that he can trigger the energy-releasing process of fusion by passing ultrasound through deuterated liquids - a phenomenon known as bubble fusion.

In February, Purdue issued a statement saying that Taleyarkhan had been cleared of internal allegations of research misconduct. But critics have questioned how the finding was reached, and

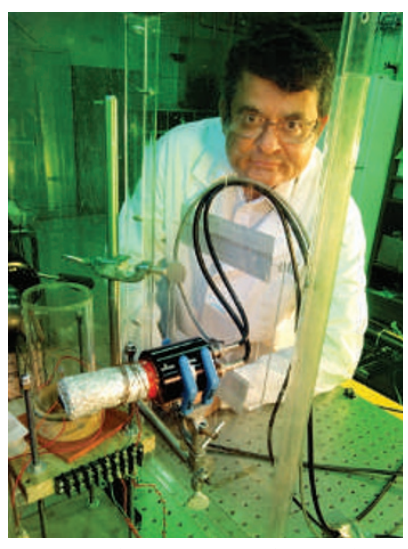

Congress has intervened in Purdue's inquiries about Rusi Taleyarkhan. into Taleyarkhan that never took place. A second inquiry cleared Taleyarkhan in February this year, but it is unclear why the two inquiries reached different conclusions. A congressional staff member who is familiar with the subcommittee's interest says that it would be a concern if the university had found procedural reasons to restrict the allegations or evidence that were available to an inquiry. "The university intends to comply fully with the committee's request. In doing so, we must attend to certain legal obligations under our own policy," Purdue has said in a statement.

"It is very rare for Congress to intervene in such matters," says Mark Frankel, director of the Scientific Freedom, Responsibility and Law Program at the American Association for the Advancement of Science in Washington DC. Between 1981 and 1995, when it was disbanded by the Republicans, the subcommittee has taken an interest in cases of alleged or actual research misconduct. These asked why the university's administration failed to say whether the fraud allegations it had received were considered (see Nature 445, 690-691; 2007).

Now, Representative Brad Miller (Democrat, North Carolina), the chairman of the oversight subcommittee, is seeking clarification. In a letter sent to Purdue's president Martin Jischke last week, Miller asked that two copies of the university's internal inquiry reports on the allegations be delivered to the subcommittee by 30 March. He says that Congress expects universities that receive federal funds to investigate when questions are raised about the integrity of research. "It was about whether they were policing the research correctly," he told Nature.

Purdue, which is based in West Lafayette, Indiana, has held two inquiries into Taleyarkhan's research. The first, which followed a report on questions about Taleyarkhan's work in Nature (see doi:10.1038/news060306-1; 2006), was announced by the university's provost Sally Mason in March 2006, and finished in June 2006. Its findings were kept confidential, but the subcommittee believes that it recommended a full-scale investigation sial hearings on allegations against Thereza Imanishi-Kari, a biologist working at Massachusetts Institute of Technology in Cambridge with the Nobel laureate David Baltimore in the late 1980s. Imanishi-Kari was later exonerated. Since then, Congress has mostly deferred to the agencies that fund research to oversee institutional processes. Frankel is not persuaded that Congress now needs to take a more active approach. Miller emphasizes that the current focus is on learning more about how Purdue handled the allegations rather than assessing the research itself.

Taleyarkhan's research has been funded by the State of Indiana, the Department of Energy through Oak Ridge National Laboratory in Tennessee, where he previously worked, and the Defense Advanced Research Projects Agency (DARPA). The inspector-general of the Office of Naval Research, which administers some DARPA grants, is conducting an inquiry into allegations against bubble-fusion research concurrent with the congressional probe. included the highly publicized and controver 